\title{
Attitudes of Physical Education Teacher Education Students towards Learning Professional Theoretical Courses
}

\author{
Tianwei Zhong \\ College of Physical Education and Health Science, Zhejiang Normal University, Jinhua, China \\ Email:2281282279@qq.com
}

How to cite this paper: Zhong, T.W. (2021) Attitudes of Physical Education Teacher Education Students towards Learning Professional Theoretical Courses. Open Access Library Journal, 8: e7519.

https://doi.org/10.4236/oalib.1107519

Received: May 12, 2021

Accepted: June 12, 2021

Published: June 15, 2021

Copyright $\odot 2021$ by author(s) and Open Access Library Inc.

This work is licensed under the Creative Commons Attribution International License (CC BY 4.0).

http://creativecommons.org/licenses/by/4.0/

\section{(c) $\underset{\mathrm{By}}{\text { (i) Open Access }}$}

\begin{abstract}
It is common for college physical education students to ignore basic theory and emphasize practicality and skills. Based on the theory of planned behavior, this research investigates the attitudes of students majoring in physical education at Zhejiang Normal University to learning theory courses, and finds out the factors affecting the attitudes of students majoring in physical education to learning theory courses, so as to improve the teaching effect of theory courses and carry out theoretical teaching reforms. For reference, the study adopted a random sampling method to conduct a questionnaire survey of 201 students majoring in physical education at Zhejiang Normal University, and also conducted interviews with 24 students. The results of the study show that attitudes are composed of likeness and result evaluation, and can have a significant impact on students' behavioral intentions. Different genders and professional theoretical course performance levels significantly affect students' scores on the evaluation of course results, thus significantly affecting attitudes. Therefore, improving students' evaluation of the results of learning theory courses is an effective means to improve students' learning attitudes.
\end{abstract}

\section{Subject Areas \\ Physical Education}

\section{Keywords}

Physical Education Majors, Theoretical Curriculum Learning, Attitude, Planning Behavior Theory

\section{Introduction}

According to the "national standards for the class teaching of undergraduate 
course of common colleges and universities" [1] and Nanjing sports institute, east China normal university the latest sports education professional training scheme [2] [3], excellent physical education graduates should grasp the basic knowledge, basic skills of sports science, and basic methods, and at the same time should have solid professional sports theory and scientific research ability.

However, it is still common for physical education majors to pay more attention to skills than to theories [4] [5]. In the class professional theory courses, students often fall asleep, play with mobile phones, even skip class and disturb class order [5]. Students' negative response to theoretical courses not only leads to their low theoretical level and humanistic quality, but also may lead to the decline of teaching quality of professional theoretical courses [6]. Basic theory courses and technical practice courses of physical education major complement each other. As far as the professional quality cultivation of physical education major students is concerned, "sports technology" complemented by "professional theory" is an inevitable development trend [4]. Based on this, it is necessary to investigate the physical education major students' attitude towards learning theoretical courses and its causes, so as to provide a reference for improving the physical education major students' attitude towards learning theoretical courses and improving the education and teaching effect.

The Theory of Planned Behavior (TPB) proposed by Ajzen [7] [8] is an effective theoretical framework for exploring the beliefs that form attitudes and the relationship between attitudes and behaviors. The theory holds that under sufficient actual control conditions, behavioral intention directly determines behavior, which is influenced by behavioral attitude, subjective norm and perceived behavioral control. Among them, behavioral attitude is an individual's evaluation of how much he likes or dislikes a certain behavior. According to the attitudinal expectation value theory of Fishbein and Ajzenz [9], individuals have a large number of beliefs about possible outcomes of behaviors, which are called behavioral beliefs. Behavioral beliefs consist of two parts. One is strength of belief, and the other is evaluation of the result of behavior. The strength of behavioral beliefs and the evaluation of outcomes determine behavioral attitudes together. At the same time, behavioral beliefs are also influenced by individual and social and cultural factors (such as intelligence, age, gender, cultural background, etc.), and indirectly affect behavioral attitudes, and ultimately affect behavioral intentions [10]. Based on TPB, the purpose of this study was to investigate the attitudes and beliefs of physical education majors in learning theory courses and their influencing factors.

\section{Research Objects and Methods}

\subsection{Respondents}

In this study, convenient sampling and group sampling were used to investigate four different grades of physical education majors in Zhejiang normal University. A total of 201 students were investigated (Table 1). 
Table 1. Distribution of gender, grade and achievement level of respondents.

\begin{tabular}{cccc}
\hline & number & $\begin{array}{c}\text { Distribution of Grade } \\
\text { (Freshman to Senior) }\end{array}$ & $\begin{array}{c}\text { Theory course score distribution } \\
\text { (from good to poor) }\end{array}$ \\
\hline male & 125 & $28: 28: 25: 44$ & $28: 65: 32$ \\
female & 76 & $15: 17: 16: 28$ & $49: 23: 4$ \\
overall & 201 & $43: 45: 41: 72$ & $77: 88: 36$ \\
\hline
\end{tabular}

\subsection{Questionnaire Survey}

Learning attitude belongs to the emotional field, which is a relatively lasting internal structure of the individual, which is difficult to observe directly and can only be measured from other parties. Attitude is not easy to quantify, and it is difficult to study and evaluate objectively. The scale draws lessons from educational psychology, psychology, social psychology and other instrumental disciplines about attitude measurement, such as the questionnaire Development Manual based on Planned Behavioral Theory and Wang he's self-designed questionnaire on athletes' Cultural Learning attitude [11], which is funded by the European Union Fund Project. Before the design of the questionnaire, 12 students were selected to use open-ended questions to conduct a survey, according to the behavior and belief related to the survey and according to the frequent occurrence of more to less, and designed the questionnaire. Select the most common behavioral beliefs in the interview and turn them into a set of statements, test these items by asking five people in the relevant population, ask the subjects to answer questions, and find out if they have any difficulties in answering these questions. Check comprehension and clarity, and revise the questionnaire according to the relevant questions. Finally, I completed the questionnaire on the attitude of the students majoring in physical education in Zhejiang normal University towards learning professional theory courses. The questionnaire "Attitudes of Physical Education Major Students of Zhejiang Normal University to Learning Professional Theory Courses", including three dimensions of students' liking for learning theory courses, result evaluation and behavioral intention. The questionnaire consists of 10 questions, which are divided into three parts: liking degree (2 questions), result evaluation (5 questions) and behavior intention ( 3 questions). After the questionnaire was prepared, it was sent to five experts in the research direction of physical education of the school for content validity test. According to the feedback of experts, the questions could accurately measure students' attitude towards learning theory courses, and the content validity was good. The questionnaire was also revised according to some suggestions from experts. The revised questionnaire was sent to 30 students twice (one week interval) for retest reliability test. Cronbach's Alpha of the three dimensions was $0.84,0.74$ and 0.78 , respectively, indicating good reliability of the three dimensions of the questionnaire.

A total of 220 copies of the revised questionnaires were sent out, 206 copies were recovered, and 201 copies were effective with a recovery rate of $93.63 \%$ and 
an effective rate of $97.57 \%$.

\subsection{The Data Processing}

In this study, SPSS 25 software was used to conduct statistical analysis on the questionnaire data of physical education major students' attitude toward learning professional theoretical courses in Zhejiang Normal University. Descriptive characteristics of the research samples were represented by mean value and standard deviation. T-test was used to analyze the gender difference in students' attitude toward learning theoretical courses. Univariance analysis was used to analyze the difference between grade level and academic course achievement level on students' attitude towards learning theory. Through the above analysis, the current situation of physical education major students' attitude towards learning professional theory courses in Zhejiang Normal University is understood, the reasons are analyzed, and relevant suggestions are put forward according to the actual situation.

\section{Results and Analysis}

\subsection{The Score of Attitude of Students Majoring in Physical Education in Zhejiang Normal University in Learning Theoretical Courses}

A total of 201 students majoring in physical education in Zhejiang Normal University were investigated, including 125 male students (62.2\%) and 76 female students $(37.8 \%)$, with a male-to-female ratio of 1.67:1 (Table 2). There were 43

Table 2. Grating of attitude of students in different ontology in the survey of attitude of professional theory course (\%).

\begin{tabular}{|c|c|c|c|c|c|c|c|}
\hline Question: & 1 points & 2 points & 3 points & 4 points & points & 6 points & 7 points \\
\hline $\begin{array}{l}\text { 1. How much you like learning } \\
\text { theoretical courses: }\end{array}$ & 5.0 & 5.5 & 14.9 & 28.9 & 31.1 & 10.9 & 8.0 \\
\hline $\begin{array}{l}\text { 2. Those who find learning theory } \\
\text { courses interesting: }\end{array}$ & 1.0 & 7.5 & 14.4 & 34.3 & 26.9 & 8.0 & 8.0 \\
\hline $\begin{array}{l}\text { 3. It is considered that it is necessary } \\
\text { to set up theoretical courses for } \\
\text { physical education majors: }\end{array}$ & 0.0 & 1.0 & 5.0 & 18.4 & 26.9 & 23.4 & 23.4 \\
\hline $\begin{array}{l}\text { 4. Theoretical courses are considered } \\
\text { more important than technical } \\
\text { courses: }\end{array}$ & 2.5 & 3.0 & 23.9 & 43.8 & 14.4 & 6.0 & 6.5 \\
\hline $\begin{array}{l}\text { 5. Most of the time, you don't want } \\
\text { to go to a theory class or do other } \\
\text { non-academic things in class: }\end{array}$ & 5.5 & 13.9 & 25.4 & 28.4 & 12.4 & 9.0 & 5.5 \\
\hline $\begin{array}{l}\text { 6. In order to find a good job, I will } \\
\text { study hard in theory courses: }\end{array}$ & 1.0 & 0.0 & 6.0 & 23.4 & 37.3 & 22.4 & 10.0 \\
\hline $\begin{array}{l}\text { 7. Willing to take time off or do other } \\
\text { things in order to study theory } \\
\text { courses: }\end{array}$ & 2.0 & 2.5 & 13.9 & 30.8 & 33.8 & 10.9 & 6.0 \\
\hline
\end{tabular}


freshmen (21.4\%), 45 sophomores (22.4\%), 51 juniors (25.4\%), and 62 seniors (30.8\%). Among the 201 students, 77 students (38.3\%) performed well in professional theory courses, 88 students (43.8\%) were average, and 36 students $(17.9 \%)$ were poor.

The average score of the students majoring in physical education in learning theoretical courses was 4.65. Students scored on a scale of 1 to 7 for liking and outcome assessment (the mean score for emotion was 4.42 , with a standard deviation of 1.27; results the mean score of the assessment dimension was 4.74 , with a standard deviation of 0.85 ), and the standard deviation was 0.90 . The higher the score, the more positive the attitude. The results of the survey show that students' attitudes towards learning theory courses vary greatly, both negative and positive.

\subsection{The Influence of Different Genders on the Attitude of Learning Professional Theory Courses}

The results of this survey show that female physical education students in Zhejiang Normal University have a significantly higher attitude towards learning professional theoretical courses than male students $(P<0.05)$ (Table 3$)$. The differences mainly exist the student to the liking of learning theory subjects, the degree of interest, the necessary degree, think theory takes up time and learning professional course helps to better practice of the 5 questions, including the title 3 "theory on the necessity of the curriculum" girl's highest score, and the degree of the differences in boys very significantly $(\mathrm{P}<0.01)$. It shows that the degree of female students' identification with theoretical courses is much higher than that of male students. In terms of the liking degree of learning theory courses (items 1 and 2), the score of female students was significantly higher than that of male students, and there was a significant difference $(\mathrm{P}<0.05)$. It shows that male students are not interested in learning theoretical courses (Table 4).

The interview results show that students of different genders all believe that learning theory courses is helpful to their own development, but the female students' expression of identity theory courses is significantly more than that of male students. In terms of the degree of liking, 25\% of male students and $33.3 \%$ of female students said they liked theoretical courses, $41.7 \%$ of male students and $58.3 \%$ of female students said they neither liked nor hated theoretical courses, or depending on the specific situation, $33.3 \%$ of male students and $8.3 \%$ of female students said they did not like theoretical courses (Table 5).

Table 3. Single factor analysis of influencing factors of students' attitude towards learning theoretical courses in Zhejiang Normal College.

\begin{tabular}{|c|c|c|c|}
\hline factors & mean value \pm standard deviation & $t$ & $\mathrm{P}$ \\
\hline \multicolumn{4}{|l|}{ gender } \\
\hline male & $4.49 \pm 0.98$ & $-3.22^{* *}$ & 0.00 \\
\hline female & $4.91 \pm 0.68$ & & \\
\hline
\end{tabular}

*shows F value; ${ }^{* *}$ shows t value. 
Table 4. The score of attitude of students of different genders in general teaching majors of Zhejiang Normal College in learning professional theoretical courses $(\bar{x} \pm s)$.

\begin{tabular}{|c|c|c|c|c|}
\hline The title & male & female & $t$ & $\mathrm{P}$ \\
\hline 1. How much you like learning theoretical courses: & $4.34 \pm 1.432$ & $4.75 \pm 0.940$ & -2.425 & 0.016 \\
\hline 2. Those who find learning theory courses interesting: & $4.19 \pm 1.435$ & $4.59 \pm 1.048$ & -2.275 & 0.024 \\
\hline $\begin{array}{l}\text { 3. It is considered that it is necessary to set up } \\
\text { theoretical courses for physical education majors: }\end{array}$ & $5.18 \pm 1.334$ & $5.83 \pm 0.958$ & -3.976 & 0.000 \\
\hline $\begin{array}{l}\text { 4. Theoretical courses are considered more important } \\
\text { than technical courses: }\end{array}$ & $4.06 \pm 1.330$ & $4.12 \pm 1.095$ & -0.300 & 0.764 \\
\hline $\begin{array}{l}\text { 5. In theory classes, getting good grades can help you } \\
\text { get a job: }\end{array}$ & $4.94 \pm 1.328$ & $5.16 \pm 1.096$ & -1.181 & 0.239 \\
\hline $\begin{array}{l}\text { 6. I think the study of theoretical courses will take up } \\
\text { my time to rest or do other things: }\end{array}$ & $3.90 \pm 1.328$ & $4.55 \pm 1.380$ & -3.308 & 0.001 \\
\hline $\begin{array}{l}\text { 7. Learning professional theory courses is conducive } \\
\text { to better practice activities: }\end{array}$ & $4.83 \pm 1.203$ & $5.36 \pm 0.989$ & -3.191 & 0.002 \\
\hline
\end{tabular}

Table 5. The degree to which the students majoring in physical education in Zhejiang normal University like the theoretical courses (gender).

\begin{tabular}{cccc}
\hline Degree of affection & Unlike-very much & normal & Like-very much \\
\hline Male & 33.3 & 41.7 & 25 \\
Female & 8.3 & 58.3 & 33.3 \\
\hline
\end{tabular}

\subsection{The Influence of Different Grades on the Attitude of Learning Professional Theory Courses}

Univariate analysis results showed that the overall attitude level of students in different grades showed no difference $(\mathrm{P}<0.05)$, and the increase of grades and learning knowledge did not make students' learning attitude to theoretical courses have a significant positive impact. Students' emotional and result evaluation of theoretical courses will change with the increase of age and knowledge, but it remains relatively stable on the whole (Table 6). The interview results show that the overall attitude of students in different grades towards the theoretical courses is relatively similar, and there is no significant difference.

\subsection{The Influence of Different Academic Achievement Levels on the Attitude of Studying Professional Theoretical Courses}

The results of this survey show that students with different academic performance levels have statistically significant differences in their attitude towards learning theoretical courses $(\mathrm{P}<0.05)$, and students with higher academic performance levels have the best attitude towards learning theoretical courses. In attitude evaluation 7 evaluation indexes, the result good students in title 3 "think it is necessary to set theory of physical education curriculum is" the highest score, and the other two students scores level there is obvious difference, that result the better students have better the value of the professional theory course, 
Table 6. Single factor analysis of influencing factors of students' attitude towards learning theoretical courses in Physical Education Major of Zhejiang Normal University.

\begin{tabular}{cccc}
\hline factors & mean value \pm standard deviation & $\mathrm{F}$ & $\mathrm{P}$ \\
\hline grade & & & \\
freshman & $4.41 \pm 1.03$ & $1.60^{*}$ & 0.19 \\
sophomore & $4.75 \pm 0.85$ & & \\
Junior year & $4.78 \pm 0.81$ & & \\
Senior year & $4.64 \pm 0.91$ & & \\
\hline
\end{tabular}

identity, and liking for theory course is the higher. Students with lower academic performance (the last $40 \%$ ) have higher academic performance than those with lower academic performance (the latter 40\%). In question 2, "they think it is interesting to learn theoretical courses", question 3, "they think it is necessary to set theoretical courses for physical education majors", question 4, "they think theoretical courses are more important than technical courses", and question 5, "they have higher academic performance in theoretical courses". The scores of "getting good grades helps to find a job" and "learning professional theoretical courses helps to better carry out practical activities" are lower than those of students with good grades (top 30\%) $(\mathrm{P}<0.05)$ and students with average grades $(30 \%-60 \%)(\mathrm{P}<0.05)$. It shows that the students with lower grades have a great difference in learning attitude towards theoretical courses from those with better grades and those with average grades. Their attitude is more negative, and their liking degree and result evaluation of theoretical courses show negative evaluation. In general, students with higher scores have better attitudes toward learning theoretical courses, while students with lower scores have worse attitudes toward learning theoretical courses (Table 7).

The interview results show that students with lower grades have a lower liking for theoretical courses. 50\% of students with lower grades clearly express their dislike for theoretical courses, while $75 \%$ of students with better grades clearly express their liking for theoretical courses. As for the result evaluation of learning theory courses, the higher the student's achievement level is, the more positive and comprehensive the evaluation of learning theory courses is.

\section{Discussion}

The results show that students' attitude towards learning theory courses is significantly related to their behavioral intention towards learning theory courses, in which the component of attitude-outcome assessment is closely related to behavioral intention. Therefore, the results of this study are consistent with expectations within the framework of the theory of planned behavior.

\subsection{The Influence of Attitude Factors on the Course Intention of Learning Theory}

The study outlines the factors (attitudinal aspects) that are closely related to 
Table 7. Single factor analysis of influencing factors of students' attitude towards learning theoretical courses in physical education major of Zhejiang Normal University.

\begin{tabular}{cccc}
\hline factors & mean value \pm standard deviation & F & P \\
\hline Performance level & & & \\
Better (top 30\%) & $4.97 \pm 0.81$ & 20.21 & 0.00 \\
Normal (30\% - 60\%) & $4.67 \pm 0.79$ & & \\
Poor (bottom 40\%) & $3.91 \pm 0.94$ & & \\
\hline
\end{tabular}

students' intention to study theoretical courses (behavior). In the theory of planned behavior, attitude refers to the individual to the behavior of the positive or negative feeling, also refers to this particular behavior by the individual evaluation formed after a conceptualization of attitude, so the attitude of the composition of this activity is often seen as a personal results significantly faith, and to the behavior of the positive or negative feeling. In this study, it was the degree to which students liked the learning theory course, and the outcome assessment was an important component of the individual's significant belief in the outcome of the behavior. The research shows that students' liking for learning theory courses does not significantly affect students' behavioral intention, but the evaluation of learning theory courses can predict students' behavioral intention. This indicates that in order to improve students' attitude towards learning theory courses and further enhance their behavioral intention towards learning theory courses, it is important to improve students' evaluation level for the result of learning theory courses. Relatively speaking, it is secondary to cultivate students' interest in learning theory courses.

\subsection{The Influence of Gender and Achievement Level Factors on Course Intention of Learning Theory}

Among the factors affecting students' outcome evaluation, gender and students' academic performance can have a significant impact on behavioral intention ( $\mathrm{P}$ $<0.01)$. There may be a certain connection between gender and academic performance. According to the results of the college entrance examination over the years, except for the English results, there is no significant gender difference in the results of the college entrance examination. However, as shown in Table 8, there are significant differences between male and female students in physical education theory $(\mathrm{P}=0.00<0.01)$ and sports anatomy $(\mathrm{P}=0.00<0.01)$, which is higher than which. From the perspective of academic year knowledge level evaluation, girls' performance is also significantly better than boys' performance. So what are the reasons for the significant differences in the scores of students of different genders after entering university? Through the analysis of the questionnaire data of students of different genders, it is found that there are significant differences between students of different genders in the result evaluation of their liking degree for learning theory courses, and girls' liking degree and result evaluation score are significantly higher than boys'. Results evaluation dimensions 
Table 8. Multiple comparison tables of students' attitudes towards learning theory courses at different achievement levels.

\begin{tabular}{|c|c|c|c|c|c|}
\hline The title & $\begin{array}{l}\text { (I) Academic results of } \\
\text { theoretical courses }\end{array}$ & $\begin{array}{l}\text { (J) Academic results } \\
\text { of theoretical courses }\end{array}$ & $\begin{array}{l}\text { Mean difference } \\
(\mathrm{I}-\mathrm{J})\end{array}$ & Standard error & $\mathrm{P}$ \\
\hline \multirow{3}{*}{ 1. How much you like learning theoretical courses: } & & general & $0.576^{*}$ & 0.176 & 0.004 \\
\hline & govu & poor & $1.759^{*}$ & 0.228 & 0.000 \\
\hline & general & poor & $1.183^{*}$ & 0.223 & 0.000 \\
\hline \multirow{3}{*}{$\begin{array}{l}\text { 2. Those who think learning theory courses are } \\
\text { interesting: }\end{array}$} & & general & 0.445 & 0.185 & 0.052 \\
\hline & good & poor & $1.637^{*}$ & 0.240 & 0.000 \\
\hline & general & poor & $1.192^{*}$ & 0.235 & 0.000 \\
\hline \multirow{3}{*}{$\begin{array}{l}\text { 3. It is necessary to set up theoretical courses for } \\
\text { physical education majors: }\end{array}$} & & general & 0.443 & 0.185 & 0.053 \\
\hline & good & poor & $1.096^{*}$ & 0.240 & 0.000 \\
\hline & general & poor & $0.653^{*}$ & 0.235 & 0.018 \\
\hline \multirow{3}{*}{$\begin{array}{l}\text { 4. Theoretical courses are more important than } \\
\text { technical courses: }\end{array}$} & & general & 0.149 & 0.190 & 1.000 \\
\hline & good & poor & $0.0758^{\star}$ & 0.246 & 0.007 \\
\hline & general & poor & $0.0609^{*}$ & 0.242 & 0.038 \\
\hline \multirow{3}{*}{$\begin{array}{l}\text { 5. Getting good grades in theory courses can help } \\
\text { you get a job: }\end{array}$} & & general & 0.141 & 0.191 & 1.000 \\
\hline & good & poor & $0.749^{*}$ & 0.247 & 0.008 \\
\hline & general & poor & $0.607^{*}$ & 0.242 & 0.039 \\
\hline \multirow{3}{*}{$\begin{array}{l}\text { 6. I think the study of theoretical courses will take } \\
\text { up my time to rest or do other things: }\end{array}$} & & general & 0.127 & 0.215 & 1.000 \\
\hline & good & poor & 0.452 & 0.278 & 0.317 \\
\hline & general & poor & 0.326 & 0.273 & 0.702 \\
\hline \multirow{3}{*}{$\begin{array}{l}\text { 7. Learning professional theoretical courses is } \\
\text { conducive to better practice activities: }\end{array}$} & & general & 0.219 & 0.173 & 0.618 \\
\hline & good & poor & $0.965^{*}$ & 0.223 & 0.000 \\
\hline & general & poor & $0.746^{*}$ & 0.219 & 0.002 \\
\hline
\end{tabular}

in which students about the importance of learning theory and learning theory course helps to find a job title score had no significant difference, difference exists in that learning theory course will take time, the question of whether or not to help practice, girls for the necessity of theoretical courses were much higher than the boys. This is consistent with the scholar Qu Mengjie's finding that female students pay more attention to their own future, while male students pay more attention to whether they can graduate successfully, care less about employment and future development than female students, and have a less objective and reasonable understanding of learning knowledge than female students, and have a strong learning motivation [12]. In addition, bourdieu, etc. [13] think, social aspects of the favorable factors and unfavorable factors with great influence on the learning process, in a broader sense, these factors to the cultural life and cultural reproduction have a huge impact, we have to consider the external social factors influence on students "mental construction" process, for example, from the employment, recruitment of teachers and coaches position pay more attention to the skill level of the individual, and the knowledge require- 
ments are relatively low, which is the advantage of most of the boys, the existing social employment environment has affected the boy to pay more attention to the skills of learning, but despise theory course of study, can't correctly understand theory course for its future development.

In addition, gender factors have a significant impact on the formation of students' learning attitude, but have no significant impact on the formation of students' behavioral intention. It may be that although boys have a poor attitude towards learning theoretical courses, they are affected by other factors (e.g. Under the influence of subjective norms and perceived behavioral control), they still maintained the same behavioral intention as girls, which needs to be further proved in future studies. This is also consistent with the theory of planned behavior theory that behavioral intention is jointly affected by attitude, subjective norms and perceived behavioral control.

There are significant differences in learning attitudes and behavioral intentions of students with different achievement levels, indicating that the achievement level has a significant impact on students' attitudes and behavioral intentions. The survey results show that students with better achievement levels have the best attitude toward theoretical courses. Further analysis found that in 10 evaluation index, the result good students in title 3 "think it is necessary to set theory of physical education curriculum is" the highest score, and the other two students scores level there is obvious difference, show results for the value of professional theory course, the better the students have a better sense of identity, And the students with better grades have better emotional experience of learning theoretical courses. Poor performance level (40\%) after the students in their title 2 "think learning theory courses interesting", title 3 "think sports education professional theory course is necessary", title 4 "thought theory course is more important than skill curriculum", topic 6 "in the theoretical study, get good grades can help to find a job", title 7 "in order to find a good job, Work hard on theoretical courses: ", 9 "willing to take up their time to rest or do other things in order to learn theoretical courses", 10 "learning professional theoretical courses is conducive to better practice activities" score lower than the students with good grades (top 30\%) $(\mathrm{P}<0.05)$ and the students with average grades $(30 \%-60 \%)(\mathrm{P}$ $<0.05$ ). It shows that the students with lower grades have a great difference in learning attitude towards theoretical courses from those with better grades and those with average grades. Their attitude is more negative, they are less fond of and interested in theoretical courses, and they agree with the questions that they are not willing to spend time on theoretical courses. According to the theory of self-efficacy, points out, the individual of their ability to perform a behavior of speculation and judgment [14], with lower scores on the students after the fall, may produce negative consequences for learning assessment, think this behavior is not suitable for their own learning theory course, which can lead to negative attitude and behavioral intention.

For the score of item 5 "most of the time, you don't want to go to a theory class or do other non-academic things in class", in many cases, students with 
different levels of achievement have no significant differences, but the differences are all below 4 points. The scores from good to bad grades are $3.95 \pm 1.346$, $3.65 \pm 1.554$ and $3.69 \pm 1.653$. It shows that most students are reluctant to take theory courses, even those with a good attitude towards learning theory courses. It shows that attitude alone is not enough to improve the behavioral intention of learning, and multiple factors should be combined to influence it. In general, students with better grades have better attitudes toward learning theoretical courses, while students with poorer grades have worse attitudes toward learning theoretical courses, which correspondingly affects their behavioral intentions.

\section{Conclusions and Limitations}

\subsection{Conclusion}

1) Students' attitude towards learning theoretical courses significantly affects their intention of learning behavior.

The results show that students' learning attitude can significantly affect their behavioral intention. As for the composition of attitude, outcome assessment is closely related to behavioral intention, while the degree of students' liking for the course has little influence on students' behavioral intention. Therefore, schools should actively guide students to correctly understand the value of theoretical courses, fully understand the fierce competition in the current society and the increasingly high professional quality requirements for sports talents, theoretical courses will play a vital role in the future development of students.

2) The achievement level significantly affects the result evaluation score of students' learning theory courses.

It is found that the better the students' academic performance, the better their behavioral intention for theoretical courses, and the worse the students' behavioral intention for theoretical courses, which is related to the students' self-efficacy for theoretical courses. How to correctly guide students, especially those with poor grades, to establish a correct understanding of the course and establish self-confidence in learning has become the key to improve student's evaluation of the results of learning theory courses. The outcome evaluation is closely related to the behavioral outcome and improving the students' outcome evaluation is helpful to enhance the behavior intention.

\subsection{Research Limitations and Future Research Directions}

The results of this study show that among the factors affecting the learning behavior intention of the students majoring in physical education, the attitude of learning theoretical courses accounts for $37.4 \%$ of the proportion. In order to further improve the accuracy of this study, it is necessary to investigate other factors (subjective norms, perceived behavioral control) that influence behavioral intention in planned behavior theory in future research.

According to the theory of planned behavior, behavioral intention is influenced by behavioral attitude, subjective norm and perceived behavioral control, 
and behavior is influenced by behavioral intention. This study proves that behavioral attitude can significantly affect behavioral intention and play a certain predictive role in behavioral intention. However, it is obvious that behavioral intention is also influenced by subjective norms and perceived behavioral control. For example, gender has a significant impact on the formation of students' learning attitude, while it does not have a significant impact on the formation of students' behavioral intention, which is obviously influenced by other factors. Therefore, in order to improve the accuracy of predicting students' behavioral intention of learning theoretical courses, the subjective norms and perceived behavioral control of students should be investigated and studied. Meanwhile, the research only investigates and predicts the behavioral intention. In the following research, the behavioral intention and behavior of students should be further studied in order to further improve the scientific and accuracy of future research to improve students' learning theory course behavior suggestions.

\section{Conflicts of Interest}

The author declares no conflicts of interest regarding the publication of this paper.

\section{References}

[1] Teaching Steering Committee of Higher Education, Ministry of Education (2018) National Standard for Teaching Quality of Undergraduate Specialty in Colleges and Universities. Higher Education Press, Beijing, 76-84.

[2] Academic Affairs Office of Nanjing University of Physical Education (2015) Nanjing Sports Institute 2016 Undergraduate Professional Training Scheme Revised Guidance. http://www.nipes.cn/jw/0d/aa/c583a3498/page.htm

[3] School of Physical Education and Health, East China Normal University (2018) 2018 Introduction to Undergraduate Enrollment Programs of School of Physical Education and Health, East China Normal University. https://mp.weixin.qq.com/s/YLeXzXKF1wsRNhr91_41aA

[4] Jing, W. and Chi, J.L. (2015) Reflection and Reconstruction of the Classroom Teaching of Theory Courses for PE Majors. Journal of Beijing Sport University, 38, 98-103.

[5] Chen, L. (2020) Research on the Relationship between Theoretical Curriculum Learning and Attitude of Physical Education Major Students. Contemporary Sports Science and Technology, 10, 187-188.

[6] Lv, J. and Huang, C.M. (2019) Investigation and Analysis on the Present Situation of Physical Education Major Students' Theory Course Learning-A Case Study of Xinjiang Normal University. Journal of Hotan Normal College, 36, 68-73.

[7] Ajzen, I. (1991) The Theory of Planned Behavior. Organizational Behavior and Human Decision Processes, 50, 179-211. https://doi.org/10.1016/0749-5978(91)90020-T

[8] Ajzen, I. (1987) From Intentions to Actions: A Theory of Planned Behavior. Advances in Experimental Social Psychology, 20, 1-63.

https://doi.org/10.1016/S0065-2601(08)60411-6

[9] Fishbein, M. and Ajzen, I. (1975) Belief, Attitude, Intention, and Behavior: An In- 
troduction to Theory and Research Reading. Addison-Wesley, Boston.

[10] Dou, W.T., Li, G.G., Li, J., et al. (2004) A Review of the Theory of Planning Behavior. Psychological Science, 12, 315-320.

[11] Wang, H. (2014) The Relationship between Cultural Learning Attitude and Behavior of Elite Athletes: And the test of the Model. Beijing University of Physical Education, Beijing.

[12] Qu, M.J. (2016) Sociological Interpretation of the Academic Achievement of Students in Physical Education Department: "Women Are Strong and Men Are Weak". Zhejiang Normal University, Jinhua.

[13] Bourdieu, H.C. (2004) Practice and Reflection. Beijing Education Science Press, Beijing.

[14] Zhang, D.K., Fang, L.L. and Ling, W.Q. (1999) The Theory and Research Status of Self-Efficacy. Psychological Trends, 7, 39-43. 